on May 5, the former of which shows a tail 20 million miles long.

Some extraordinary phenomena were observed at Victoria (B.C.) at about 7 p.m. (local M.'T.) on May 18 . The sun appeared to be in a state of rotation, emitting bright flashes of light at frequent intervals. These were probably unusual refraction phenomena, possibly produced by the interposition of cometary matter, and are recorded by an octogenarian, Mr. Helmcken, who has never seen similar phenomena before.

In No. 8, vol. Ixx., of the Monthly Notices there are more than a dozen papers dealing with observations of the comet's position, its physical characteristics, and its spectrum.

The Rivista di Astronomia, No. 6, contains some ancient records of the comet, reproduced by Father Stein, one of which shows that Halley's comet was observed in Italy for about fifty days in 1066 ; it became lost in the solar rays on April I9, and reappeared, as an evening star, on April 24 .

The Accurate Measurement of Photographs.--In all photographic astronomical researches the results are more or less vitiated by errors introduced by the optical apparatus, including the eye and brain of the observer, employed in their reduction. To eliminate these errors, Prof. E. C. Pickering proposes, in Harvard College Observatory Circular No. I55, the employment of an automatic registering apparatus. Briefly, he suggests that the negative to be measured be passed between a constant illumination and the two balanced arms of a bolometer. As the star image, or spectral line, comes in between the heat source and the bolometer, some heat would be cut off, and the galvanometer in the circuit would show a deviation, which could be registered automatically. The galvanometer curve would thus become a record of the positions and intensities of the star images or the lines in the spectrum, and the method, especially for spectrum work, should certainly be tried by someone having the necessary bolometric apparatus or selenium cells at their disposal.

Observations of Perseids in roog.-In No. 31 , vol. iii., of the Mitteilungen der Nikolai-Hauptsternwarte zu Pulkowo, Herr S. Beljawsky describes the observations of Perseids made at Simëis on August IO, II, and I2, I009. The horary rates of the meteors observed on these three dates were 21,60 , and 17 respectively, and the positions of the radiants were $49^{\circ}+60^{\circ}$ (5 obs. $; 45^{\circ}+56^{\circ}$ (15 obs.); and $43^{\circ}$, $+55^{\circ}$ (8 obs.), respectively. On August II there appeared to be another radiant at $62^{\circ}$, $+16^{\circ}$, from which four meteors appeared to emanate, but the determination is uncertain.

Results from the Micrometric Observations of Eros, 1900.-During the opposition of Eros in 1900, a number of observers made micrometric comparisons between the planet and neighbouring stars. The results from a number of observatories have been reduced at Cambridge, and Mr. Hinks now discusses them in No. 8 of the Monthly Notices. The individual results agree generally, and give as the most probable value for the solar parallax $8.806^{\prime \prime} \pm 0.004$.

\section{WILD PLANTS ON WASTE LAND IN LONDON.}

THE waste ground between Aldwych and the Strand has been colonised by a variety of plants, most of which show luxuriant growth. Many of the colonists have fruits or seeds adapted to wind distribution, as in the case of the winged fruit of the sorrel (Rumex acetosa), and of the plumed seeds of the hairy willow herb (Epilobium hirsutum) and French willow, or rose bay (E. angustifolium), by far the most conspicuous plant on the ground. It is of interest that $E$. angustifolium, which is absent in many of the waste places of London, occurs in the garden of Fountain Court, near the Strand. Among wind-distributed forms are also numerous Compositæ, the fruits of which are furnished with a pappus; these include the spear thistle (Cirsum lanceolatum), the groundsel (Senecio vulgaris) and its ally $S$. viscosus, the dandelion (Taraxacem vulgare), the butter bur (Tussilago petastes), and the Canadian flea- bane (Erigeron canadense). Fruits and seeds of these various types might be blown with some readiness from neighbouring districts, or from one part of London to another.

To a varying extent, wind may be also efficient in carry ing the seeds of hedge mustard (Sisymbrium officinale), London rocket (S. irio), which appeared in quantity after the Great Fire of 1066, and shepherd's purse (Capsella bursa pastoris); and the same is the case with chickweed (Stelloria media), white campion (Lychius alba), opium poppy (Papaver somniferum), a garden escape, frequently established in waste places, great plantain (Plantago major), pale persicaria (Polygonum lapathifolium), and scentless mayweed (Matricaria inodorata). In several of the above the seed is small or flattened, but it is not elaborately adapted to wind dispersal, and it may be questioned whether wind alone will account for the presence of these plants. A probable auxiliary exists in the sparrow, through the alimentary canal of which various seeds and fruits no doubt pass, and it is not unlikely that other become attached to its feet by means of the sticky London mud. It will be remembered that Darwin in the "Origin of Species" describes eighty-two plants as springing from the earth obtained from the feet of a single partridge. This method of distribution no doubt accounts for the presence of Dutch or white clover (Trifolium repens) and of two balsams, the pink-flowered Impatiens glandulifera and a white variety. The explosive fruit characteristic of this genus could certainly not shoot its seeds across the traffic of a London street. Possibly cats may be effective as agents of distribution in this case, and they may also account for the presence of cleavers (Galium Aparine), the hooked fruits of which would readily cling to their fur.

Among garden escapes, the marigold, nasturtium ( $=$ Tropæolum), wallfower, and a species of Prunus can be observed, as well as the opium poppy mentioned above; in connection with these, and with many of the wild species also, the neighbourhood of Covent Garden must be recailed.

The above list is by no means exhaustive, none of the grasses, for instance, having been mentioned; in one or two cases the identification had to be made from a distance and through the fence surrounding the waste ground.

\section{AGRICULTURAL INVESTIGATIONS IN} EGYPT.1

SEVERAL important events are chronicled in the current "Year-book of the Khedivial Agricultural Society." The scope of the society has recently been extended by the formation of a section dealing with farm animals, the object of which is to effect as much improvement as possible in the livestock of the country. Twenty stallions have already been distributed over the country, a number of selected cows have been acquired from which good stud bulls can in time be sent out, and a herd of buffaloes has been purchased with a view to the establishment of a heavy milking strain. In addition, an experimental farm of about 160 acres has been acquired near Cairo, and an arrangement has been effected with the State Domains Administration whereby a considerable tract of land is to be set aside for the raising of cotton or wheat seed of good quality. Finally, the society has directed attention to the diminished yield of cotton in proportion to the area sown. A committee was appointed to investigate the matter, and has already issued a report.

A considerable proportion of the year-book is taken up by Mr. Lawrence Balls's studies of Egyptian cotton. A detailed account is given of the results of a single cross made in 1905 between Afifi and Truitt Big Boll. The fourth generation is now growing, and, although the cross has no special economic value, and the results are in some ways incomplete, the record is a very valuable one, and throws much light on production of cotton varleties on Mendelian lines. The synthesis of a commercially useful cotton is a tedious business. Desirable characters are mostly dominant over undesirables, except where the

1 The Year-Book of the Khedivial Agricultural Society, Cairo, 1909.

Pp. xv+239. (Glasgow: The University Press, 1910.)
The Cairo Scientific Journal. Vol. iv., No. 43.

No. 2 I 28 , VOL. 84 ] 